\title{
The Ubiquinone Content of Animal Tissues
}

\section{A SURVEY OF THE OCCURRENCE OF UBIQUINONE IN VERTEBRATES}

\author{
By A. T. DIPLOCK \\ Walton Oaks Experimental Station, Vitamins Ltd., Tadworth, Surrey \\ AND G. A. D. HASLEWOOD \\ Department of Biochemistry, Guy's Hospital Medical School, London, S.E.1
}

(Received 11 January 1967)

\begin{abstract}
1. A method was developed for the analysis of ubiquinone in animal tissues and the recovery of added ubiquinone tested in liver of the rat, Crocodylus porosus and Squalus acanthias. 2. The ubiquinone content of heart, liver and gut (or breast muscle in birds) was measured in 67 different animal species, selected to be representative of all the vertebrate classes. 3. The suggestion is advanced that the possession of appreciable amounts of endogenous tissue ubiquinone is usually characteristic of evolutionarily advanced vertebrates, and the biological and biochemical significance of the results is discussed.
\end{abstract}

It has been evident since the discovery of the ubiquinones that they are widely distributed in Nature. In spite of this, no serious systematic study has been made of the natural distribution of ubiquinone: attempts to systematize the observations of a number of workers were made by Lester \& Crane (1959), Ramasarma (1961) and Crane (1962). It was shown that ubiquinone occurs in vertebrates, invertebrates, higher plants, the algae and a wide range of bacteria and micro-organisms. If the values recorded for the cardiac ubiquinone content of vertebrates are examined, their wide diversity is at once apparent: thus Lester \& Crane (1959) record a value of $19 \mu \mathrm{g}$./g. of heart for Rana catesbiana and of $15 \mu \mathrm{g} . / \mathrm{g}$. of heart for Rana pipiens, whereas Bunyan, Edwin, Diplock \& Green (1961) found $192 \mu \mathrm{g}$./g. of wet tissue in the heart of the woodpigeon, Columba palumbus.

However, comparison of the values obtained by different workers, using various methods of analysis, may not be legitimate. The recovery of ubiquinone may not be quantitative when methods, satisfactory for, for example, relatively large amounts of rat tissue, are used to examine small amounts of tissues that may themselves differ greatly in their lipid content and composition. Further, dietary factors may play a part, since ubiquinone is a constituent of many foodstuffs (Page, Gale, Koniuszy \& Folkers, 1959). Threlfall \& Glover (1962) showed that when ubiquinone-10 was given to rats (which normally have predominantly ubiquinone-9; Diplock, Edwin, Green, Bunyan \& Marcinkiewicz, 1960), much ubiquinone-10 was found in the liver whereas the cardiac muscle was devoid of the 'foreign' ubiquinone-10. (The numerals indicate the number of isoprene units/ mol.) This observation has been confirmed by us many times in rats and chicks fed on diets containing torula yeast, a considerable source of ubiquinone-7. Thus the cardiac ubiquinone content is probably the most representative of the true content, and other tissues may be contaminated with ubiquinone of dietary origin.

The need for a survey of the occurrence of ubiquinone in vertebrates was therefore apparent and the ubiquinone content of three tissues from 67 species has been measured, by a method that has been rigorously tested for the recovery of added ubiquinone on tissue from three species of widely differing tissue lipid composition.

\section{EXPERIMENTAL AND RESULTS}

\section{Selection of analytical methods}

It is possible that the tissues of different animals contain materials that affect the analysis of the tissue for ubiquinone by, for example, destruction of the quinone at some stage of the analysis. Before the present survey could be undertaken, it was necessary to obtain an analytical method that had been rigorously checked for recovery of small amounts of ubiquinone and was applicable to a diversity of tissues. Rat, crocodile and dogfish liver were chosen, since preliminary experiments with the last-named two animals had shown that crocodile tissues often contain a large amount of an unidentified unsaponifiable dark-orange oil and that dogfish tissues contain large amounts of squalene, both of which substances may interfere with the analytical procedures. Because of the rarity and small size of some of the species to be examined, the method of analysis chosen had 


\section{Table 1. Recovery of ubiquinone after paper chromatography}

Sheets $(23 \mathrm{~cm} . \times 57 \mathrm{~cm}$.) of Whatman no. 4 paper for chromatography were impregnated with zinc carbonate and fluorescein as described by Green, Marcinkiewicz \& Watt (1955), except that the solution contained 20 p.p.m. (w/v) of sodium fluorescein. The papers were dipped in $3 \%(\mathrm{v} / \mathrm{v})$ liquid paraffin in light petroleum (b.p. $60-80^{\circ}$ ) and quantities of ubiquinone (UQ) applied to the paper: five different amounts of ubiquinone-10 and ubiquinone-9 were chromatographed, alone and together in a mixture. Chromatograms were developed by the descending technique in aq. $75 \%(\mathrm{v} / \mathrm{v})$ ethanol for $5 \mathrm{hr}$. Spots were located under u.v. light and eluted by $3 \mathrm{ml}$. of ethanol for assay.

\begin{tabular}{|c|c|c|c|}
\hline \multicolumn{2}{|c|}{ UQ-9 alone } & \multicolumn{2}{|c|}{ UQ-10 alone } \\
\hline $\begin{array}{c}\text { UQ-9 } \\
\text { added } \\
(\mu \mathrm{g} .)\end{array}$ & $\begin{array}{c}\text { UQ-9 } \\
\text { recovered } \\
(\%)\end{array}$ & $\begin{array}{c}\text { UQ-10 } \\
\text { added } \\
(\mu \mathrm{g} .)\end{array}$ & $\begin{array}{c}\text { UQ-10 } \\
\text { recovered } \\
(\%)\end{array}$ \\
\hline $\mathbf{5}$ & $88 \cdot 7$ & 5 & $89 \cdot 8$ \\
\hline 10 & $89 \cdot 7$ & 10 & $91 \cdot 3$ \\
\hline 26 & $95 \cdot 8$ & 26 & $92 \cdot 1$ \\
\hline 51 & $91 \cdot 7$ & 51 & $90 \cdot 6$ \\
\hline 126 & $93 \cdot 4$ & 126 & $94 \cdot 7$ \\
\hline
\end{tabular}

\begin{tabular}{cccc}
\multicolumn{4}{c}{ UQ-9+UQ-10 together } \\
$\begin{array}{c}\text { UQ-9 } \\
\text { added } \\
(\mu \mathrm{g} .)\end{array}$ & $\begin{array}{c}\text { UQ9- } \\
\text { recovered } \\
(\%)\end{array}$ & $\begin{array}{c}\text { UQ-10 } \\
\text { added } \\
(\mu \mathrm{g} .)\end{array}$ & $\begin{array}{c}\text { UQ-10 } \\
\text { recovered } \\
(\%)\end{array}$ \\
5 & $87 \cdot 6$ & 5 & $89 \cdot 1$ \\
10 & $92 \cdot 3$ & 10 & $90 \cdot 0$ \\
26 & $89 \cdot 7$ & 26 & $92 \cdot 3$ \\
51 & $90 \cdot 1$ & 51 & $98 \cdot 7$ \\
126 & $94 \cdot 5$ & 126 & $91 \cdot 2$
\end{tabular}

to be applicable to small amounts of tissue: a lower limit of $1.0 \mathrm{~g}$. was selected.

Analytical methods for the measurement of ubiquinone in animal tissues comprise: (1) the extraction of ubiquinone from the tissue and its separation from saponifiable lipids; (2) the purification of the resultant unsaponifiable fraction and the separation of ubiquinone from other tissue constituents; (3) the measurement of the purified ubiquinone.

Spectrophotometric measurement. The potassium borohydride reduction method of Crane, Widmer, Lester \& Hatefi (1959) was used. $\Delta E_{1 \mathrm{~cm}}^{1 \%}$ in ethanol at $275 \mathrm{~m} \mu$ for ubiquinone-10 was 142 and for ubiquinone-9 was 152 . The latter value was obtained (since it was not given by Crane et al. 1959) by using a pure synthetic sample of ubiquinone-9 kindly given by Dr $\mathrm{O}$. Isler.

Paper chromatography. A modification of the method of Diplock, Green, Edwin \& Bunyan (1960b) was used. In a preliminary experiment, a range of quantities of ubiquinone9 and -10 were run on paper for $16 \mathrm{hr}$. in the partition system of Diplock et al. (1960b). Larger quantities (e.g. 125 $\mu \mathrm{g}$.) were recovered quantitatively, but there was a progressive loss as the quantity was decreased, only about $65 \%$ of a $5 \mu \mathrm{g}$. sample being recovered. The losses might have been due to the protracted chromatography, during which very small amounts of ubiquinone were distributed over a large surface and oxidation could readily have occurred. Whatman no. 1 paper was therefore replaced by Whatman no. 4 and the experiment repeated: the time of chromatography required to achieve satisfactory separation was now only $5 \mathrm{hr}$. Table 1 gives the results and shows that recovery of small amounts of ubiquinone was satisfactory. Further experiments showed that the recovery of smaller amounts could be further improved when tissue lipids were also present on the paper. Small amounts of authentic ubiquinone homologues were chromatographed alongside the tissue extracts, enabling a positive identification of the homologue present to be made.

Column chromatography. The recovery of ubiquinone from tissues of Crocodylus porosus, Squalus acanthias and the laboratory rat was hampered by several difficulties, which were finally overcome by the method described and with the result shown in Table 2.
It should be noted that the Decalso F used was of British manufacture (Permutit Co. Ltd., London, W.4); material imported from the U.S.A. was unsatisfactory for lipid chromatography. Recovery of $10 \mu \mathrm{g}$. of ubiquinone was satisfactory.

Extraction of ubiquinone from tissues and saponification. The saponification of ubiquinone-containing tissues and the saponification of lipids derived from them was the subject of a comparative study by Diplock, Green, Bunyan \& McHale (1966). These authors concluded that the wholetissue saponification method of Mervyn \& Morton (1959) was the most satisfactory of the five methods examined and this was used in the present work. However, Diplock et al. (1966) used a $5 \mathrm{~g}$. sample of rat liver for their study and it was necessary to examine the recovery of ubiquinone both from smaller quantities of one tissue and also from the same quantities of tissue from the three species used in the column-chromatography recovery experiment (Table 2). Tables 3 and 4 give the details and results. Recoveries of ubiquinone were satisfactory; further, it should be emphasized that the results presented in Table 4 represent overall recoveries for the whole analytical procedure.

\section{Survey of the occurrence of ubiquinone in the tissues of vertebrate species}

Sources of material and storage. The major source of material was the Zoological Society of London; tissues were removed at post-mortem examination and deep-frozen in polythene containers at $-25^{\circ}$. Occasionally, for some very small species, the entire carcass was deep-frozen: tissues showing pathological changes were rejected.

Sea fish were obtained from a trawler operating from Fleetwood, Lancashire. The fish were dissected immediately they were caught and the organs placed in polythene bags, which in turn were placed in larger bags containing crushed ice and stored at $0^{\circ}$ until the ship returned to port. Immediately on arrival, the tissues were transferred to a refrigerated van and taken to London where they were weighed and deep-frozen. River fish were obtained from anglers at Penton Hook on the River Thames; they were dissected at once and the organs placed in polythene bags until they could be weighed and deep-frozen. In addition, 
Table 2. Recovery of ubiquinone added to tissue unsaponifiable lipids, after column chromatography

Liver (90g.) from rat, Crocodylus porosus and Squalus acanthias was saponified by the method of Mervyn \& Morton (1959) and the resulting unsaponifiable material dissolved in $90 \mathrm{ml}$. of light petroleum (b.p. $60-80^{\circ}$ ). This was divided into $185 \mathrm{ml}$. samples for each tissue: to three of these no ubiquinone was added and to the remaining 15 samples, amounts of ubiquinone (UQ) were added to give approx. 10, 50, 100, 500 and $1000 \mu \mathrm{g}$. of added ubiquinone. Each mixture was prepared in triplicate and was applied to a $10 \mathrm{~g}$. Decalso $\mathrm{F}$ column, which was washed with $30 \mathrm{ml}$. of light petroleum (b.p. $40-60^{\circ}$ ) and the ubiquinone fraction eluted with $30 \mathrm{ml}$. of $35 \%$ $(\mathrm{v} / \mathrm{v})$ ether in light petroleum. The eluates were chromatographed on paper and the ubiquinone was estimated spectrophotometrically: the ubiquinone content of the original solutions was estimated simultaneously.

Amount of UQ-10 added ( $\mu \mathrm{g}$.

Gross amount of UQ-10 recovered $(\mu \mathrm{g} .)^{*}$

Mean net amount of UQ-10 recovered ( $\mu \mathrm{g}$.)

Mean \% recovery of UQ-10 added
(A) Rat

(B) Crocodile

(C) Dogfish

(A) Rat

(B) Crocodile

(C) Dogfish

(A) Rat

(B) Crocodile

(C) Dogfish
$321 \cdot 4 \pm 4 \cdot 1$

$$
172 \cdot 6 \pm 4 \cdot 5
$$

$96 \cdot 5 \pm 1 \cdot 5$

Nil

Nil

Nil

Nil

Nil

Nil $\mathbf{9 \cdot 4}$

$329 \cdot 8 \pm 1 \cdot 1$

$180 \cdot 7 \pm 6 \cdot 2$

$104 \cdot 9 \pm 2 \cdot 2$

$8 \cdot 4$

$8 \cdot 2$

$8 \cdot 4$

$89 \cdot 2$

$87 \cdot 6$

$89 \cdot 7$
$47 \cdot 6$

$364 \cdot 8 \pm 1 \cdot 7$

$214.4 \pm 1.9$

$137 \cdot 7 \pm 2 \cdot 0$

$43 \cdot 4$

$41 \cdot 9$

$41 \cdot 2$

$91 \cdot 2$

$88 \cdot 2$

$86 \cdot 5$
$96 \cdot 3 \quad 489 \cdot 7$

$411 \cdot 2 \pm 6 \cdot 2$

$259 \cdot 9 \pm 9 \cdot 6$

$185 \cdot 3 \pm 3.9$

$89 \cdot 8$

$87 \cdot 4$

$88 \cdot 8$

$93 \cdot 3$

$90 \cdot 8$

$92 \cdot 3$
$981 \cdot 9$

$761 \cdot 5 \pm 12 \cdot 0 \quad 1260 \cdot 1 \pm 5 \cdot 7$

$619 \cdot 6 \pm 11 \cdot 3 \quad 1048 \cdot 4 \pm 7 \cdot 6$

$560 \cdot 8 \pm 4 \cdot 3 \quad 986 \cdot 1 \pm 10 \cdot 2$ $440 \cdot 1 \quad 938 \cdot 7$

447.1 $\quad \mathbf{8 7 5 \cdot 9}$

$464 \cdot 3 \quad 889 \cdot 6$

$90 \cdot 0 \quad 95 \cdot 6$

$\mathbf{9 1 \cdot 3} \mathbf{8 7 \cdot 2}$

$94 \cdot 8 \quad 90 \cdot 6$

\footnotetext{
* Means \pm S.D. of three values.
}

\section{Table 3. Analysis of ubiquinone in rat liver}

Five rat livers were minced to give a homogeneous mixture and amounts of tissue weighed out in duplicate. Samples were saponified by the method of Mervyn \& Morton (1959) and the extracts subjected to column and paper chromatography (see Tables 1 and 2) before spectrophotometric assay.

$\begin{array}{lcccccc}\text { Wt. of minced liver taken (g.) } & 10 & \mathbf{7 \cdot 5} & 5 \cdot 0 & 2 \cdot 5 & 1 \cdot 0 & 0 \cdot 5 \\ \text { Ubiquinone-9 found }(\mu \mathrm{g} . / \mathrm{g} .)^{*} & \mathbf{9 8 \pm 4 \cdot 2} & \mathbf{9 4 \pm 4 \cdot 2} & \mathbf{9 8 \pm 5 \cdot 6} & \mathbf{8 7 \pm 4 \cdot 2} & \mathbf{8 4} \pm 4 \cdot 2 & 69 \pm 2 \cdot 8\end{array}$

* Means \pm S.D. of two determinations.

\section{Table 4. Recovery of ubiquinone-10 from liver of three different species}

Samples of liver from the rat, Crocodylus porosus and Squalus acanthias were minced to give a homogeneous mixture and ten $5 \mathrm{~g}$. samples were weighed out. Amounts of ubiquinone-10 (UQ-10) were added (in duplicate) to the ethanol used for saponification by the method of Mervyn \& Morton (1959). Ubiquinone (UQ-9+UQ-10 together) was measured after column and paper chromatography (see Tables 1 and 2).

$\begin{array}{llccrcc}\text { Amount of UQ-10 added }(\mu \mathrm{g} .) & & \text { Nil } & 24 \cdot 6 & 95 \cdot 4 & 511 \cdot 3 & 1028 \\ \text { Gross amount of UQ-10 } & \text { (A) Rat } & 488 \pm 40 & 509 \pm 4 & 569 \pm 6 & 957 \pm 27 & 1446 \pm 8 \\ \text { recovered }(\mu \mathrm{g} .)^{*} & \text { (B) Crocodile } & 151 \pm 7 & 175 \pm 13 & 240 \pm 33 & 623 \pm 6 & 1090 \pm 8 \\ & \text { (C) Dogfish } & 81 \pm 2 & 102 \pm 2 & 163 \pm 14 & 545 \pm 18 & 1008 \pm 4 \\ \text { Mean net amount of UQ-10 } & \text { (A) Rat } & \text { Nil } & 21 \cdot 8 & 80 \cdot 6 & 469 \cdot 3 & 958 \cdot 6 \\ \text { recovered }(\mu \mathrm{g} .) & \text { (B) Crocodile } & \text { Nil } & 22 \cdot 7 & 88 \cdot 3 & 471 \cdot 2 & 938 \cdot 6 \\ & \text { (C) Dogfish } & \text { Nil } & 21 \cdot 3 & 81 \cdot 6 & 463 \cdot 7 & 927 \cdot 2 \\ \text { Mean \% recovery of UQ-10 } & \text { (A) Rat } & \text { Nil } & 88 \cdot 6 & 84 \cdot 5 & 91 \cdot 8 & 93 \cdot 2 \\ \text { added } & \text { (B) Crocodile } & \text { Nil } & 92 \cdot 3 & 92 \cdot 6 & 92 \cdot 2 & 91 \cdot 4 \\ & \text { (C) Dogfish } & \text { Nil } & 87 \cdot 6 & 86.5 & 90 \cdot 7 & 90 \cdot 2\end{array}$

$*$ Means \pm S.D. of two determinations.

certain species were obtained from their natural habitat in the Surrey countryside. Tissues of Myxine glutinosa were obtained from Oslo, flown to London and the ubiquinone assays conducted immediately on arrival; the alcohol used to preserve the tissues in transit was used as the solvent for the saponification.
The practice of deep-freezing tissues subsequently to be used for ubiquinone analysis has been examined by Diplock et al. (1960b), who stored rat and rabbit tissues for up to 28 weeks at $-20^{\circ}$ without apparent destruction of ubiquinone. We cannot be certain that tissues obtained as described had not lost ubiquinone before they were deep-frozen; the 
point was tested only with Squalus acanthias and the laboratory rat.

Conduct of analysis. Three tissues were studied, namely heart, liver and gut; in the birds, breast muscle was studied in place of gut. Hearts were opened and blood and bloodclots remaining in the chambers were removed; livers were allowed to drain on a Petri dish to eliminate blood and fluid collected in the blood vessels and sinuses. Usually the entire duodenum was analysed, together with sufficient ileum to give a suitable sample; it was slit longitudinally and the contents were wiped away gently.

Analyses were carried out by the methods given above; usually the saponification and column chromatography were carried out on one day and paper chromatography and measurement on the following day, the ubiquinone-enriched fraction being stored overnight at $-25^{\circ}$. The results are given in Table 5 .

\section{DISCUSSION}

In placing any interpretation on the results, one is immediately faced with the difficulty that probably most of the species examined had eaten food containing ubiquinone. Some of this exo-

\section{Table 5. Ubiquinone in different animal forms}

Ubiquinone-9 (?) was found in heart and ubiquinone-10 in liver and gut in Agnatha and Chondrichthyes; ubiquinone-10 was found in all organs of all other animals except Mus muscularis and Rattus norvegicus, which had ubiquinone-9. N.D., Not detected.

Ubiquinone ( $\mu \mathrm{g} \cdot / \mathrm{g}$. of wet tissue)

Higher class of animal

Species

Heart Liver Gut

\section{FISHES}

Agnatha

Cyclostomata

Hagfish, Myxine glutinosa

$4 \cdot 8$

$22 \cdot 9$

$24 \cdot 3$

Chondrichthyes

Holocephali

ELASMOBRANCHII

Pleurotremata

Rabbit fish, Chimaera monstrosa

N.D. N.D. N.D.

Dalatias licha

Lesser spotted dogfish, Scyliorhinus caniculas

Greater spotted dogfish, Scyliorhinus stellaris

Spinax niger

Greenland shark, Somniosus microcephalus

\section{Hypotremata}

Spined dogfish, Squalus acanthias

Blonde ray, Raja brachyura

Torpedo, Torpedo nobiliana

$\begin{array}{rrr} & & \\ 1 \cdot 8 & 3.7 & 3.9 \\ 2.7 & 23 \cdot 6 & 7.5 \\ 1.0 & 4 \cdot 1 & 2.3 \\ \text { N.D. } & 3 \cdot 9 & 1.9 \\ \text { N.D. } & 8 \cdot 3 & \text { N.D. } \\ \text { N.D. } & 14.8 & 5 \cdot 1 \\ 2.5 & 1.8 & 2.1 \\ 1 \cdot 1 & 6 \cdot 2 & 1.0\end{array}$

\section{OSTEICHTHYES}

Teleoster

Ostariophysi Cyprinidae

Other Teleostei
Isospondyli

Haplomi
Acanthopterygii
Anacanthini

Percomorphi

\section{Heterosomata}

Pediculati

\author{
Bream, Abramis brama \\ Carp, Cyprinus carpio \\ Roach, Rutilus rutilus \\ Herring, Clupea harengus \\ Salmon, Salmo salar \\ Trout, Salmo trutta \\ Pike, Esox lucius \\ Torsk, Brosme brosme \\ Cod, Gadus morhua \\ Hake, Merluccius merluccius \\ Blue ling, Molva byrkelange \\ Ling, Molva molva \\ Coalfish, Pollachius virens \\ Forked-beard hake, Urophysis blennoides \\ Grey mullet, Mugil sp. \\ Red mullet, Mullus barbatus \\ Perch, Perca fluviatilis \\ Mackerel, Scomber scombrus \\ Halibut, Hippoglossus hippoglossus \\ Megrim, Lepidorhombus whiffiagonis \\ Angler fish, Lophius piscatorius
}

$151 \cdot 0$

$40 \cdot 2$

$35 \cdot 0$
$54 \cdot 1$

10.8 
Table 5.-continued

Higher class of animal AMPHIBIANS

Caudata

Anura

\section{REPTILES}

Testudines

Cryptodira

Testudinoidea

Testudinidae

Chelonioidea

Sauria

Dermochelidae

Iguania

Iguanidae

Agamidae

Scincomorpha

Lacertidae

Diploglossa

Varanidae

\section{Serpentes}

Henophidia

Boidae

Caenophidia

Colubridae

Crocodilia

Viperidae Viperinae

Crocodylidae

\section{BIRDS}

\section{Galliformes}

\section{Columbiformes}

Passeriformes

\section{MAMMALS}

Metatheria

Marsupialia

\section{EUTHERIA} Macropodidae

Insectivora

Edentata

Rodentia

Muridae

\section{Carnivora}

Canidae

\section{Species}

Newt, Triturus vulgaris

Toad, Bufo bufo vulgaris

Bullfrog, Rana catesbiana

Edible frog, Rana esculenta

Frog, Rana temporaria

Testudo graeca

Leathery turtle, Dermochelys coriacea

Banded basilisk, Basiliseus vittatus

Iguana iguana

Bell's dabb lizard, Uromastyx acanthinurus

Green lizard, Lacerta viridis

Monitor, Varanus bengalensis

Varanus niloticus

Boa constrictor constrictor

Coluber gemonensis

European grass-snake, Natrix natrix

Natrix septemvittata

Indian ratsnake, Ptyas mucosus

Adder, Vipera berus

Alligator mississippiensis

Caiman crocodylus

Caiman, Caiman latirostris

Crocodylus acutus

Crocodylus niloticus

Crocodylus porosus

Domestic fowl

Domestic turkey

Woodpigeon, Columba palumbus

Canary, Serinus canarius

Wallaby, Protemnodon eugenii

European hedgehog, Erinaceus europaeus

Armadillo, Dasypus novemcinctus

House mouse, Mus musculus

Laboratory rat, Rattus norvegicus

Fox, Canis vulpes

Ubiquinone ( $\mu \mathrm{g} . / \mathrm{g}$. of wet tissue)

\begin{tabular}{rrr} 
Heart & Liver & \multicolumn{1}{c}{ Gut } \\
& & \\
18.2 & 6.9 & $2 \cdot 2$ \\
$15 \cdot 1$ & $8 \cdot 7$ & $9 \cdot 3$ \\
14.9 & $8 \cdot 2$ & $10 \cdot 3$ \\
$15 \cdot 3$ & 7.5 & $17 \cdot 3$ \\
11.4 & 8.7 & 18.5
\end{tabular}

$\begin{array}{rrr}5.5 & 10.9 & 8 \cdot \\ 11 \cdot 1 & - & - \\ & & \\ 23.9 & 41 \cdot 7 & 3 \cdot \\ 14.6 & 11 \cdot 7 & 10 \cdot \\ 17.9 & 33.2 & 4 \cdot 7 \\ 14 \cdot 7 & 34.0 & 24 \cdot 2 \\ 36.5 & 21.9 & 20 \cdot 0 \\ 31.7 & 15.2 & 2 \cdot 0\end{array}$

$8 \cdot 0$

$3 \cdot 4$

$24 \cdot 2$

$0 \cdot 0$

$2 \cdot 0$

$\begin{array}{lll}47 \cdot 7 & 11 \cdot 7 & 18 \cdot 0\end{array}$

$\begin{array}{lll}89 \cdot 4 & 24 \cdot 8 & 21 \cdot 4\end{array}$

$\begin{array}{lll}189.0 & 41.8 & 30.8\end{array}$

$151 \cdot 0 \quad 32 \cdot 4 \quad 14 \cdot 3$

$72 \cdot 4 \quad 71 \cdot 0 \quad 14 \cdot 4$

$\begin{array}{lll}57 \cdot 7 & 16 \cdot 7 & 11 \cdot 3\end{array}$

$\begin{array}{lll}3 \cdot 1 & 1 \cdot 2 & 0.6\end{array}$

$2 \cdot 3 \quad 22 \cdot 1 \quad 26 \cdot 5$

$4 \cdot 1 \quad 0 \cdot 4 \quad 0 \cdot 1$

$1.5 \quad 18.5 \quad 3.9$

$1 \cdot 1 \quad 7 \cdot 2 \quad 1 \cdot 3$

$8 \cdot 2 \quad 38 \cdot 1 \quad 0 \cdot 1$

Heart Breas

$18.0 \quad 13.0 \quad 1.4$

$13 \cdot 3 \quad 37 \cdot 1 \quad 10 \cdot 0$

$\begin{array}{lll}174.5 & 31.3 & 317.8\end{array}$

$\begin{array}{rrr}\mathbf{2 4 2} \cdot 3 & \mathbf{5 2} \cdot 0 & \mathbf{3 8} \cdot 0\end{array}$

$\begin{array}{crc}\text { Heart } & \text { Liver } & \text { Gut } \\ 78.5 & 30 \cdot 0 & 15 \cdot 3\end{array}$

$\begin{array}{lll}108 \cdot 3 & 19 \cdot 0 & 23 \cdot 1\end{array}$

$\begin{array}{lll}23.5 & 12 \cdot 8 & 32 \cdot 2\end{array}$

$\begin{array}{lll}236.7 & 58.8 & 82.3\end{array}$

$\begin{array}{lll}199.3 & 77.0 & 63.7\end{array}$

$\begin{array}{lll}240 \cdot 6 & 86 \cdot 3 & 24 \cdot 3\end{array}$ 
genous ubiquinone may have entered the tissues. The present discussion is therefore confined to cardiac ubiquinone concentrations, since it has been shown that these are unlikely to be much affected by dietary ubiquinone (Threlfall \& Glover, 1962). The cardiac ubiquinone concentrations found are discussed systematically below.

Agnatha. This group comprises the hagfishes (Myxini) and lampreys (Petromyzonidae). The Agnatha are obviously lower in their plane of organization than other vertebrates and are specialized for their peculiar mode of life; they probably comprise a truly primitive class. The very low cardiac ubiquinone content of Myxine glutinosa is therefore of considerable interest. The amount found is so nearly insignificant that at once a question fundamental to this study is raised: is it possible that a primitive animal such as this is incapable of synthesizing or utilizing ubiquinone biochemically? The amount of ubiquinone in the heart of the marine and river lampreys, Petromyzon marinus and $\boldsymbol{P}$. fluviatilis, was measured by Pennock, Morton, Lawson \& Laidman (1962); they recorded values of 70 and $51 \mu \mathrm{g} . / \mathrm{g}$. respectively. The lampreys are probably distinctly more advanced than the hagfishes (Brodal \& Fänge, 1963).

Chondrichthyes. The cardiac ubiquinone content of every chondrichthyan studied was so low as to raise serious doubts about the presence of endogenous ubiquinone in the tissues of these fishes. In two species, Squalus acanthias and Chimaera monstrosa, an attempt was made to plot the u.v.absorption spectra of the material eluted from the ubiquinone-9 position on the chromatogram from the cardiac tissue: these showed maxima at 262, 274 and $278 \mathrm{~m} \mu$ and at 262,272 and $279 \mathrm{~m} \mu$ in ethanol respectively : the definition was poor, owing to the small amount of material available, and the 274 and $272 \mathrm{~m} \mu$ peaks became smaller after the addition of potassium borohydride. Two possibilities exist; this is either the spectrum of an unidentified substance or that of a trace of ubiquinone9 mixed with another compound.

Osteichthyes. The osteichthyan fishes examined were all teleosts. Their cardiac ubiquinone concentrations showed great diversity, and all possessed appreciable amounts of ubiquinone. The view that a high cardiac ubiquinone content may be a late evolutionary development finds some support in a study of the teleosts, but anomalies make it desirable to study many more species.

Amphibia. Uncertainty about the origin of the amphibians makes the finding of very low cardiac ubiquinone concentrations in all species studied of particular interest. The constancy of values within the Anura is also noteworthy.

Reptilia. The archosaurs are among the least progressive of reptiles and it is therefore of interest that the cardiac ubiquinone content of all species of Crocodylidae studied was so low as to raise doubts as to whether its presence has biochemical significance. In contrast with our findings with chondrichthyans, however, the small amounts obtained were identified by the characteristic sharp absorption peak at $275 \mathrm{~m} \mu$. In the two species of Testudines examined, the cardiac ubiquinone content was similar to that of the archosaurs. The cardiac ubiquinone concentrations of all the lizards examined fell into a group intermediate between those of the archosaurs and of the snakes. The latter group had cardiac ubiquinone concentrations in general commensurate with those of mammals.

Aves. The two species examined from the Orders Columbiformes and Passeriformes have exceptionally high heart ubiquinone concentrations, consistent with their position as advanced vertebrates. It is possible that the low ubiquinone content in the Galliformes studied is an adaptation to a somewhat inactive habit.

Mammalia. The heart of the single metatherian studied contained an appreciable amount of ubiquinone. Since the Metatheria are more primitive than the Eutheria, all species examined of which have high cardiac ubiquinone concentrations, it seems probable that the ability to synthesize and utilize ubiquinone is general in marsupial and eutherian mammals.

Examination of the values obtained for the cardiac ubiquinone content of all the species studied could lead to the conclusion that the possession of appreciable amounts of endogenous tissue ubiquinone may be a characteristic of evolutionarily advanced vertebrates. However, anomalous results make it desirable that many more species be studied, and other explanations for the variation observed must be considered. It is possible, for instance, that, because of the respiratory function of ubiquinone, the amount present in a tissue may be related to the respiratory rate of that tissue. Since it has been shown that mitochondria from widely differing sources behave similarly and have similar composition, it is possible that ubiquinone concentration may be related to the number of mitochondria and hence to the oxidative metabolism of the tissue. A comparative study of the mitochondrial content and uxidative metabolism of vertebrate species is therefore needed to resolve this question.

It is necessary, finally to consider in some detail the chondrichthyan fishes. Clearly, if endogenous ubiquinone is present in the hearts of these animals, it is present only in small amounts. Nazir \& Magar (1964) measured ubiquinone concentrations in tissues of the shark Carcharias ellioti Day and reported a cardiac content of ubiquinone-9 of $31 \mu \mathrm{g} \cdot / \mathrm{g}$. They state, however, that the u.v. 
absorption showed 'a comparatively flat peak' at $275 \mathrm{~m} \mu$, which is of interest in view of our observation of three peaks in this region of the spectrum of material isolated from certain chondrichthyans. Daniel \& Redfearn (1966) measured the content of ubiquinone in skeletal muscle from Squalus acanthias and recorded a level of $0.007 \mu$ mole of ubiquinone-9/g. of wet muscle (equivalent to $6 \mu \mathrm{g} . / \mathrm{g}$.$) . Cardiac tissue is unlikely to contain$ exogenous ubiquinone. Daniel \& Redfearn (1966) state that this is also true of skeletal muscle; no reference is given for this assumption. It is, however, noteworthy that the ubiquinone content found by them in skeletal muscle is of the same order as that found by us (assuming that the peak at $278 \mathrm{~m} \mu$ was due to ubiquinone) in cardiac tissue. The diet of Squalus acanthias probably contains much ubiquinone-10 (see Jenkins, 1936; Steven, 1930), so that it is possible that such ubiquinone-9 as may be present in tissue of chondrichthyans may be endogenous in origin.

It is well established that the mitochondrial ubiquinone content of certain mammalian tissues is considerably in excess of that which would be required if ubiquinone were to act simply as a carrier in electron transport. The dogfish has been shown to contain mitochondria (Grief \& Alfano, 1964) and, further, mitochondria from such diverse sources as turtle heart (Mersmann \& Privitera, 1964), carp heart (Gumbmann \& Tappel, 1962) and crab hepatopancreas (Beechey, Burrin \& Baxter, 1963) are remarkably similar to mammalian mitochondria in cytochrome content and ratio, oxidative activity and structure. If ubiquinone and cytochrome $c$ are required for the electron-transport system on an equimolar basis, then the minimal quantity of ubiquinone required to fulfil this function can be calculated. Although Hagihara, Morikawa, Sekuzu, Horio \& Okunuki (1956) found only $1.88 \mu$ moles of cytochrome $\mathrm{c} / \mathrm{kg}$. of ox heart, Morrison, Hollocher, Murray, Marinetti \& Stotz (1960) found a mean of $6.5 \mu$ moles $/ \mathrm{kg}$. in ten different preparations. Assuming that all this cytochrome $c$ is in the mitochondria, then the amount of ubiquinone-10 required for electron transport would be similar, i.e. $6.5 \times 863 \mu \mathrm{g}$. $/ \mathrm{kg}$. of mitochondria $(=5.61 \mu \mathrm{g} . / \mathrm{g}$.). This amount is near to the limit of detection of our method (which requires $5 \mu \mathrm{g}$. applied to the paper chromatogram). Thus, if the chondrichthyan heart contains merely sufficient ubiquinone to work the electron-transport system and we assume that the cytochrome $c$ content of the tissues of these fishes is similar to that of ox heart, it is entirely possible, since only about $2 \mathrm{~g}$. of heart muscle was usually analysed, that such ubiquinone as may have been present was undetected by our method. However, such assumptions as we have made in this argument may not be valid and we consider it proper to raise the question whether ubiquinone functions in electron transport in lower vertebrates as it is thought to do in mammals. It cannot be assumed that metabolic pathways elucidated in higher mammals necessarily exist in detail in all vertebrates.

We are grateful to Professor R. A. Morton, F.R.S., and Dr O. Isler, Hoffman-La Roche, Basle, Switzerland, for generous gifts of ubiquinone. The co-operation of Dr L. Harrison Matthews and Mr R. N. T.-W.-Fiennes of the Zoological Society of London, Dr F. Walvig, Biologiske Stasjon, Universitetet, Oslo, Norway, Commander J. Kelly of Fleetwood, Lancashire, and members of the scientific staff of the British Museum (Natural History) is gratefully acknowledged.

\section{REFERENCES}

Beechey, R. B., Burrin, D. H. \& Baxter, M. I. (1963). Nature, Lond., 198, 1277.

Brodal, A. \& Fänge, R. (1963). The Biology of Myxine. Oslo: Universitetsforlaget.

Bunyan, J., Edwin, E. E., Diplock, A. T. \& Green, J. (1961). Nature, Lond., 190, 637.

Crane, F. L. (1962). Biochemistry, 1, 510.

Crane, F. L., Widmer, C., Lester, R. L. \& Hatefi, Y. (1959). Arch. Biochem. Biophys. 87, 198.

Daniel, R. M. \& Redfearn, E. R. (1966). Biochem. J. 100, $8 \mathrm{c}$.

Diplock, A. T., Edwin, E. E., Green, J., Bunyan, J. \& Marcinkiewicz, S. (1960a). Nature, Lond., 186, 554.

Diplock, A. T., Green, J., Bunyan, J. \& McHale, D. (1966). Brit. J. Nutr. 20, 95.

Diplock, A. T., Green, J., Edwin, E. E. \& Bunyan, J. (1960b). Biochem. J. 76, 536.

Green, J., Marcinkiewicz, S. \& Watt, P. R. (1955). J. Sci. Fd Agric. 6, 274.

Grief, R. C. \& Alfano, J. A. (1964). Gen. comp. Endocrin.4, 339.

Gumbmann, M. \& Tappel, A. L. (1962). Arch. Biochem. Biophys. 98, 262.

Hagihara, B., Morikawa, I., Sekuzu, I., Horio, T. \& Okunuki, K. (1956). Nature, Lond., 178, 630.

Jenkins, J. T. (1936). The Fishes of the British Isles, 2nd ed., p. 322. London: F. Warne and Co. Ltd.

Lester, R. L. \& Crane, F. L. (1959). J. biol. Chem. 234, 2169.

Mersmann, H. J. \& Privitera, C. A. (1964). Amer. J. Physiol. 206, 980.

Mervyn, L. \& Morton, R. A. (1959). Biochem. J. 72, 106.

Morrison, M., Hollocher, T., Murray, R., Marinetti, G. \& Stotz, E. (1960). Biochim. biophys. Acta, 41, 334.

Nazir, D. J. \& Magar, N. G. (1964). Biochem. J. 90, 268.

Page, A. C., Gale, P. H., Koniuszy, F. \& Folkers, K. (1959). Arch. Biochem. Biophys. 85, 474.

Pennock, J. F., Morton, R. A., Lawson, D. E. M. \& Laidman, D. L. (1962). Biochem. J. 84, 637.

Ramasarma, T. (1961). J. sci. industr. Res. 20A, 492.

Steven, G. A. (1930). J. mar. biol. Ass. U.K., 16, 677.

Threlfall, D. R. \& Glover, J. (1962). Biochem. J. 82, 14 P. 